Iren Peltekova

ORCID: 0000-0003-0045-9578

Uniwersytet Sofijski im. św. Klimenta z Ochrydy

Bułgaria

\title{
Баскетбол в колясках как инструмент повышения социального положения человека
}

\author{
Wheelchair basketball as a tool for raising social inclusion
}

https://doi.org/10.34739/sn.2019.19.09

\begin{abstract}
Аннотация: В статье представлены возможности баскетбола в колясках как средства помощи людям с ограниченными возможностями в выборе лучшей социальной жизни. Обращается внимание на историю спорта, необходимость адаптированной программы, подготовленных педагогических кадров и спортивного инвентаря для участия в тренировочных и состязательных соревнованиях.
\end{abstract}

Ключевые слова: спортивные возможности, баскетбол в колясках, люди с ограниченными возможностями, социальная интеграция

\begin{abstract}
This article presents potentials of wheelchair basketball as an opportunity to support disabled people in order to raise their social inclusion. In the article attention is paid to the history of sport and to the necessities of introducing the adapted program. Qualified pedagogical specialists are needed together with sports facilities for participating in training and for official competition activities.
\end{abstract}

Keywords: sports opportunities, disabled people, wheelchair basketball, social inclusion

Одним из главных условий полноценного развития человека и его успешной социализации в жизни является его спортивная деятельность.

«Спортивная деятельность с её специфическими формами воспринимается как культурное, социально-экономическое и политическое явление и как основополагающая необходимость развития и совершенствования. Спорт - это особый способ выражения, общения и существования. С помощью средств физической культуры формируется этносоциальный характер человека, что способствует установлению его существования в зависимости от его врожденных и приобретенных качеств» [Туманова, 2013]. 
Цель работы: исследовать взаимосвязь баскетбола в колясках и развития социальной интеграции человека.

Объект исследования: баскетбол в колясках как социальное явление.

Предмет исследования: характеристика теорий баскетбола в колясках в развитии социального положения человека.

В условиях усиления конкурентной борьбы, важнейшим преимуществом для любого человека становится его здоровье. Сложная социальная ситуация, высокая заболеваемость, ухудшение социальноэкономической обстановки, неблагоприятные экологические условия и другие неблагоприятные факторы требуют выработки определённой спортивной системы в работе по оздоровлению человека.

К сожалению, не все люди физически здоровы. Многие из них молодые люди, которые были активны, но были ранены в инцидентах. Таким образом, их двигательная активность снижается, что приводит к ограничениям в их социальном общении: эти люди испытывают много стресса, впадают в депрессивные состояния и отчуждаются от друзей. Вот где важная роль спорта и возможностей, которые он предлагает людям с ограниченными возможностями.

Игра в баскетбол адаптирована к баскетболу на колясках с желанием создать истинное равенство между здоровыми людьми и людьми с ограниченными возможностями. Цель баскетбола в колясках - дать людям с ограниченными возможностями шанс участвовать в спортивных соревнованиях и в тренировочных занятиях.
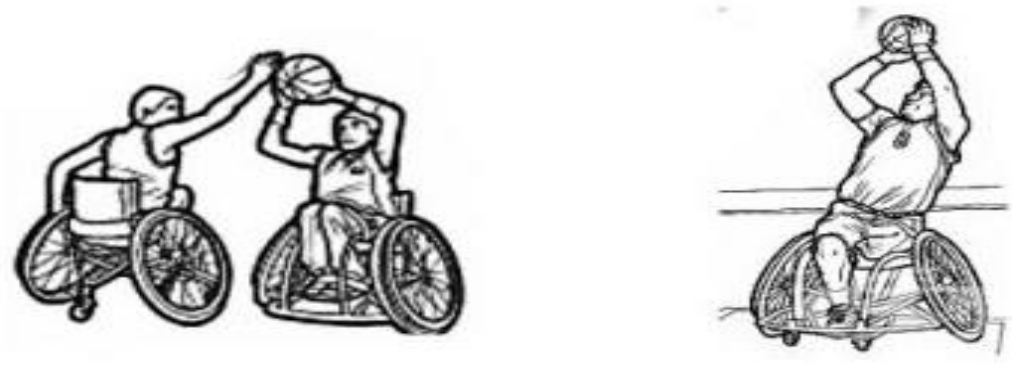

Баскетбол на инвалидных колясках - это баскетбол, в котором играют люди с различными физическими недостатками, которые лишают их от возможности заниматься здоровым спортом. К ним относятся 
расщелина позвоночника, врожденные дефекты, церебральный паралич, паралич в результате несчастного случая, ампутации (стопы или другие) и многие другие нарушения. Международная федерация баскетбола на колясках (IWBF) является руководящим органом этого вида спорта.

История баскетбола в колясках началась в рамках программы реабилитации в одной больнице из Бакингемшира, Англия, между 1944 и 1946 годами. Людвиг Гутман адаптировал игру в баскетбол для нужд возвращающихся инвалидов Второй мировой войны. Баскетбол на колясках становится популярным и разыгрывается по всему миру. До настоящего времени было проведено 11 чемпионатов мира с участием стран Европы, Северной и Южной Америки, Африки, Азии и Океании.

Четыре команды были сорормированы в Болгарии, и с 2016 года проводятся государственные чемпионаты. Ранее проводились только показательные игры для популяризации спорта. Одним из первых баскетболистов на колясках является Борис Томов. Ему было 44 года, бывший теннисист, но уже шесть лет он занимается баскетболом и уже является капитаном болгарской команды - «София-Балкан». Он говорит следующее: «Команда - это отличный социальный проект. Мы собираемся два раза в неделю в баскетбольном зале. Эти люди становятся друзьями, помогают друг другу, а затем приводят своих друзей. За пять лет набор играков увеличился в четыре раза. Баскетбол на колясках очень полезен для нас, а также служит для реабилитации» [Николова, 2016].

Создавая спортивные баскетбольные программы, ориентированные на эту конкретную группу людей, можно восстановить их социальную и эмоциональную жизнь. Чтобы эта инициатива была успешной, должны быть подготовлены спортивные специалисты для работы с этими людьми, а также адаптивное оборудование (коляски). К сожалению, не хватает финансовых ресурсов для этого оборудования и тому подобного. А. Хиджов и Н. Панайотов (2013) - тренеры шести горнолыжников и лыжников представили Болгарию на Специальных Олимпийских Зимних Играх в Пхеньяне, в Южной Корее, с 29 января по 05 февраля. 2013: «Государство, не только в лице государственного сообщества, но и во всех учреждениях, должно уделять гораздо больше внимания спортсменам с ограниченными интеллектуальными 
возможностями, чтобы иметь возможность охватить больший процент из них в своей деятельности с ограниченными интеллектуальными возможностями в спорте и, следовательно, значительно разширить общение в обществе. Более 15000 человек из 113 стран, 3257 спортсменов и тренеров, 1300 семей, 1000 представителей прессы, 1500 почетных гостей, 7800 волонтеров и сторонников приняли участие в этом празднике спорта для людей с ограниченными интеллектуальными возможностями». Те же авторы продолжают: «Игры объединили мир через спорт и прославили таланты и умения людей с ограниченными интеллектуальными возможностями, сформировав новую глобальную культуру непрерывности. Они были памятным моментом празднования различий в талантах, и, по мнению участников, родители и тренеры способствовали созданию более успешного мира для всех » [Хиджов, Панайотов, 2013].

Занимаясь баскетболом в инвалидной коляске, участники развивают дисциплину, повышают уверенность в себе и столь необходимую самостоятельность. Спортсмены, участвующие в этой спортивной деятельности, учатся лучше работать в команде, развивать свои навыки и достигать новых целей в жизни. И наконец, что не менее важно, им рекомендуется вести здоровый образ жизни, потому что ряд статистических исследований показал, что люди с ограниченными возможностями чаще бывают физически неактивными, что приводит к увеличению ожирению. По мнению Г. Дякова, Петков П. [2015] «Моторная активность - это активность, присущая живым организмам. Это неизменная природно-биологическая потребность человека, без которой его жизнь невозможна. Установлено, что при иммобилизации в его организме наблюдается ряд негативных изменений, связанных с атрофией и снижением функций практически всех органов и систем» [Дякова, Петков, 2015].

В заключение полезно подчеркнуть, что поиск общественной поддержки, адекватных государственных ресурсов и интегрирующих механизмов для поддержки участия людей с ограниченными возможностями в спортивных мероприятиях способствует достижению ожидаемых результатов в улучшении их социального положения. Сотрудничество между самими спортсменами, спортивным сообществом, семьей и государством может создать лучшую социальную среду для людей с ограниченными возможностями. Потому что 
отношение к этим людям может определить, насколько демократичным и социальным является государство.

\section{Literatura [Литература]}

Dyakova G., Petkov P., (2015), Sravnyavanena pokazatelina fizicheskagodnost pri studentki, v: Pedagogichesko obrazovaniye - traditsiii s"vremennost, Veliko T"rnovo. [Дякова Г., Петков П., (2015), Сравняване на показатели на физическа годност при студентки, в: Педагогическо образование - традиции и съвременност, Велико Търново].

Khidzhov A., Panayotov N., (2013), Analiz na uchastiyeto na Blgarskata delegatsiya v VI - te Svetovni zimni igri na "Spesh"lolimpiks", v: Sbornik nauchnakonferentsiya nafiliala na VTU "Sv. Sv. Kirili Metodiy", Vratsa. [Хиджов А., Панайотов Н., (2013), Анализ на участието на Българската делегация в $\mathrm{VI}-$ те Световни зимни игри на "Спешъл олимпикс", В: Сборник научна конференция на филиала на ВТУ “Св. Св. Кирил и Методий”, Враца].

Nikolova Vl., Boris Tomov za basketbola $v$ invalidni kolichki. http://bgbasket.com/new.php?id=57780 [13.02.2019]. [Николова Вл., Борис Томов за баскетбола в инвалидни колички, http://bgbasket.com/new.php?id=57780 [13.02.2019]].

Tumanova B., (2013), Pluvaneto kato faktor zarazreshavaneto na problemi pri razvitiyeto $i \quad v$ "zpitaniyetona lichnosttaprez periodana det-stvotoi yunoshestvoto, $v$ sluchaitena khora $s$ intelektualni zatrudneniya, v: Formiranena grazhdanina i profesionalista vusloviyata nauniversitet-skotoobrazovaniye, Izdatelstvo YEKS - PRES, Gabrovo. [Туманова Б., (2013), Плуването като фактор за разрешаването на проблеми при развитието и възпитанието на личността през периода на детството и юношеството, в случаите на хора с интелектуални затруднения, в: Формиране на гражданина и професионалиста в условията на университетското образование, Издателство ЕКС-ПРЕС, Габрово]. 